\title{
Morphometric evaluation of condylar cartilage of growing rats in response to mandibular retractive forces
}

\author{
Milena Peixoto Nogueira de Sá1, Jacqueline Nelisis Zanoni², Carlos Luiz Fernandes de Salles³, \\ Fabrício Dias de Souza4, Uhana Seifert Guimarães Suga' ${ }^{5}$, Raquel Sano Suga Terada ${ }^{6}$
}

Introduction: The mandibular condylar surface is made up of four layers, i.e., an external layer composed of dense connective tissue, followed by a layer of undifferentiated cells, hyaline cartilage and bone. Few studies have demonstrated the behavior of the condylar cartilage when the mandible is positioned posteriorly, as in treatments for correcting functional Class III malocclusion. Objective: The aim of this study was to assess the morphologic and histological aspects of rat condyles in response to posterior positioning of the mandible. Methods: Thirty five-week-old male Wistar rats were selected and randomly divided into two groups: A control group (C) and an experimental group (E) which received devices for inducing mandibular retrusion. The animals were euthanized at time intervals of 7, 21 and 30 days after the experiment had began. For histological analysis, total condylar thickness was measured, including the proliferative, hyaline and hypertrophic layers, as well as each layer separately, totaling 30 measurements for each parameter of each animal. Results: The greatest difference in cartilage thickness was observed in 21 days, although different levels were observed in the other periods. Group E showed an increase of $39.46 \%$ in the total layer, reflected by increases in the thickness of the hypertrophic (42.24\%), hyaline (46.92\%) and proliferative (17.70\%) layers. Conclusions: Posteriorly repositioning the mandible produced a series of histological and morphological responses in the condyle, suggesting condylar and mandibular adaptation in rats.

Keywords: Articular cartilage. Angle Class III malocclusion. Mandibular condyle.

Introdução: a superfície do côndilo da mandíbula é constituída por quatro camadas: uma externa (constituída de tecido conjuntivo denso), seguida pela camada de células indiferenciadas, cartilagem hialina e osso. Poucos estudos demonstraram o comportamento da cartilagem condilar quando a mandíbula é posicionada posteriormente, como na terapia para correção de Classe III funcional. Objetivo: o objetivo desse trabalho foi avaliar os aspectos morfológicos e histológicos do côndilo de ratos, em resposta ao posicionamento posterior da mandíbula. Métodos: foram selecionados 30 ratos Wistar, machos, com cinco semanas de vida, aleatoriamente divididos em dois grupos: grupo controle (GC) e grupo experimental (GE), que recebeu dispositivos para induzir a retrusão mandibular. Os animais foram sacrificados após 7, 21 e 30 dias de experimento. Para a análise histológica, foi realizada a mensuração da espessura condilar total, incluindo as camadas proliferativa, seriada e hipertrófica, assim como cada camada separadamente, totalizando 30 medições para cada parâmetro, de cada animal. Resultados: a maior diferença na espessura da cartilagem foi observada em 21 dias, apesar de serem verificados níveis diferentes nos demais períodos. Em GE, foi possível observar um aumento de 39,46\% na camada total, representado pelo aumento na espessura das camadas hipertrófica $(42,24 \%)$, seriada $(46,92 \%)$ e proliferativa $(17,70 \%)$. Conclusões: o reposicionamento posterior da mandíbula produziu uma série de respostas histológicas e morfológicas no côndilo, e sugerem a ocorrência de uma adaptação condilar e mandibular em ratos.

Palavras-chave: Cartilagem articular. Má oclusão Classe III de Angle. Côndilo mandibular.

${ }^{1} \mathrm{MSc}$ in Integrated Dentistry, State University of Maringá (UEM).

${ }^{2} \mathrm{PhD}$ in Cell Biology and Associate professor at the Department of Morphological Sciences, UEM.

${ }^{3} \mathrm{PhD}$ in Pediatric Dentistry, University of São Paulo (USP). Adjunct professor at the Department of Dentistry, UEM.

${ }^{4} \mathrm{PhD}$ in Endodontics, College of Dentistry - Pernambuco.

${ }^{5}$ Masters student in Integrated Dentistry, UEM.

${ }^{6} \mathrm{PhD}$ in Dentistry, USP. Associate professor at the Department of Dentistry, UEM.
How to cite this article: Sá MPN, Zanoni JN, Salles CLF, Souza FD, Suga USG, Terada RSS. Morphometric evaluation of condylar cartilage of growing rats in response to mandibular retractive forces. Dental Press J Orthod. 2013 July-Aug;18(4):113-9.

Submitted: May 15, 2011 - Revised and accepted: April 17, 2012

" The authors report no commercial, proprietary or financial interest in the products or companies described in this article.

Contact address: Raquel Sano Suga Terada

Av. Mandacaru, 1550 - Bairro Mandacaru - Maringá/PR - Brazil

CEP: 87080-000 - E-mail: rssterada@uem.br 


\section{INTRODUCTION}

The surface of the mandibular condyle consists of four layers: an external layer, composed of dense connective tissue, followed by a layer of undifferentiated cells, hyaline cartilage and bone. The condyle features two key functions: joint function and endochondral growth. ${ }^{16,19}$ Similarly to other articular cartilages in the body, the mandibular condylar cartilage can withstand biologically-induced stress.

However, it differs in several biological aspects, such as ontogenetic development, postnatal growth and histological structures. ${ }^{19}$ One peculiarity of the condylar cartilage is its adaptive capacity due to endochondral ossification. ${ }^{14,18}$ This feature may enable orthopedic appliances to modify not only the direction, but also the amount of mandibular growth. ${ }^{16}$

Nevertheless, few studies have shown the behavior of the condylar cartilage when the mandible is positioned posteriorly as in the treatment of functional Class III malocclusion.

The number of studies evaluating the adaptive capacity of rat condylar cartilage under stress significantly increased in the past years. Some authors found an increase in cellular response and growth when the mandible is held in a protrusive position. ${ }^{8,14,15,21}$ Other researchers ${ }^{9,18}$ have shown modifications in the two condyles when the mandible is deviated laterally. The result obtained in lateral postural deviation indicates that the lateral displacement of the mandible can (a) increase the thickness of the condylar cartilage and proliferation of precondroblasts on the contralateral side, and (b) decrease them on the ipsilateral side. ${ }^{4,18}$

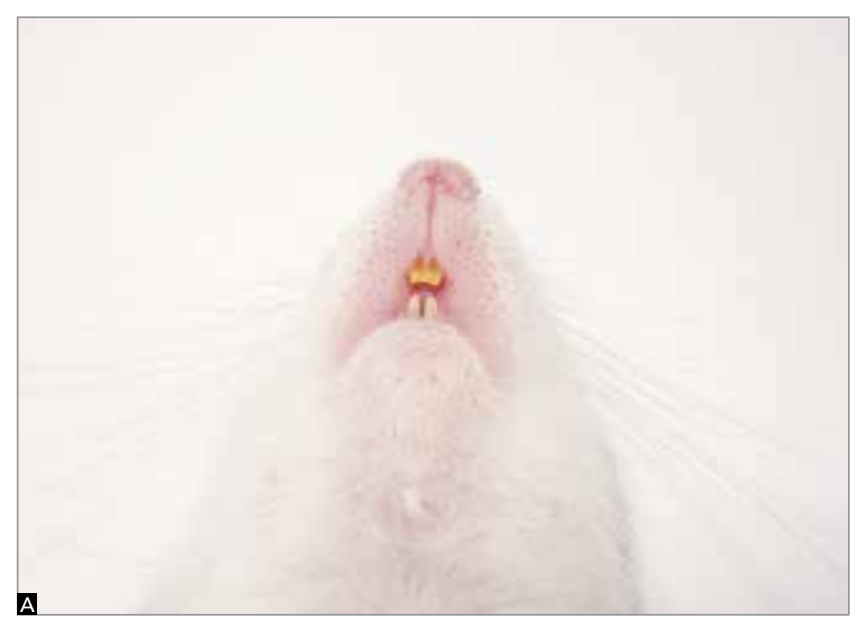

Figure 1 - Occlusal view of Wistar rat. A) Control group. B) Experimental group.
Controversial reports on occlusion and temporomandibular disorder (TMD) can be found in the literature. Some authors believe that there is no scientific evidence that malocclusion is a risk factor for TMD, ${ }^{7,12}$ whereas others found a high correlation between TMD and posterior condylar displacement due to malocclusion, ${ }^{6,11,22}$ especially deep overbite in patients with Angle Class I or Class II malocclusion. Nevertheless, many changes arising from the posterior positioning of the condyle are still unknown.

In this context, the objective of this study was to assess the characteristics of the condylar cartilage of young rats during mandibular retrusion.

\section{MATERIAL AND METHODS}

Thirty 5-week-old male Wistar rats (Fig 1A) were randomly divided into two groups: control (C) and experimental (E). Both groups were fed with a soft diet and water ad libitum. Animals were maintained under standard conditions with a $12 \mathrm{~h}$ light/ dark cycle and controlled temperature $\left(23^{\circ} \mathrm{C}\right)$.

This study was approved by Maringá State University (UEM) Institutional Review Board, under No. 080/2008.

The 12 animals of group E were fitted with an intraoral device capable of promoting mandibular setback and modifying functional occlusion (Fig 1B). To this end, impressions of the mouths of two animals were taken to enable the devices to be fabricated and adjusted on dental casts. Subsequently, acetate trays were fabricated to allow a standardized technique.

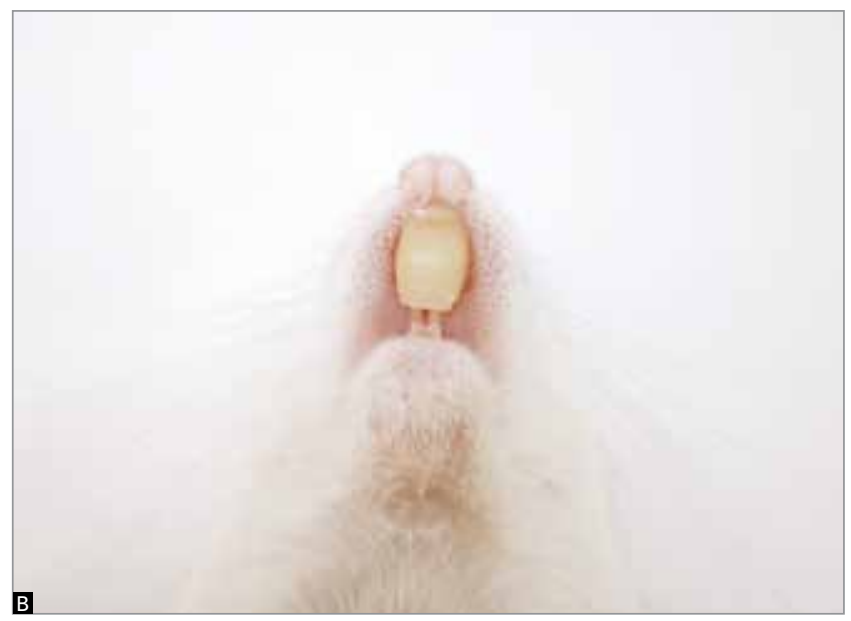


The devices were fabricated with Z250 composite resin (3M Dental Products, St. Paul, MN / USA) on the upper incisors of group E. The animals were anesthetized with an intramuscular injection of 1:1 combination of Ketamine (10\%) and Xylazine (2\%) at a dosage of 0.5 $\mathrm{mg} / 100 \mathrm{~g}$. Once the animals were under anesthesia, the teeth were etched, self-etching primer was applied, and a thin layer of adhesive was applied and light-activated. The acetate matrix was filled with adhesive and fitted on the teeth of the rats for final light-activation.
Group C received no device and, therefore, corresponded to the characteristics of a normal occlusion (Fig 2). In group E, on the other hand, the presence of the devices and their inclination prevented the mouth from closing in habitual occlusion, which caused mandibular retrusion (Fig 3).

\section{Tissue preparation}

The animals were sacrificed with an overdose of anesthetic after a treatment period of 7,21 and 30 days.

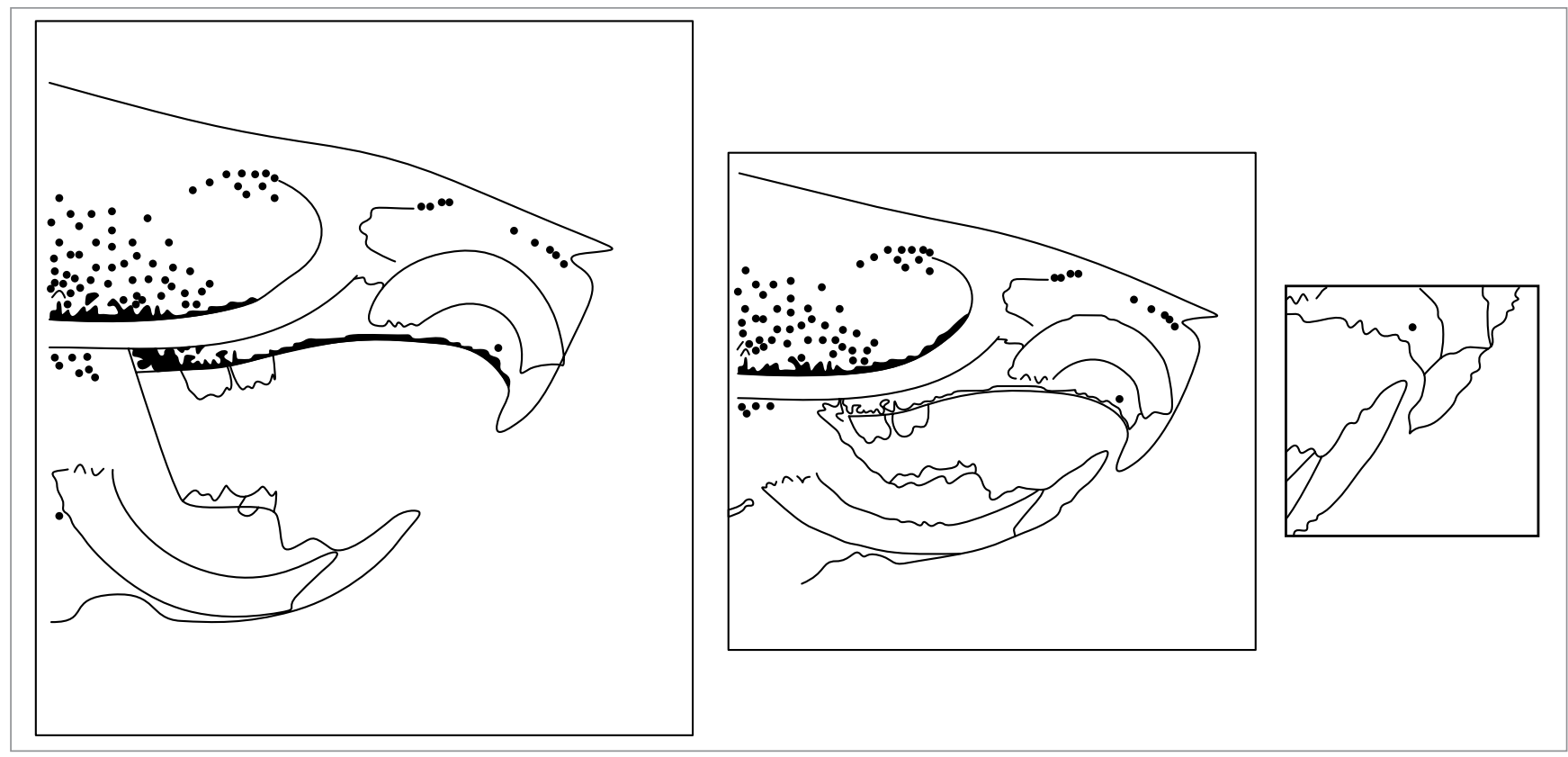

Figure 2 - Schematic sequence of habitual occlusion in a rat (Control Group).
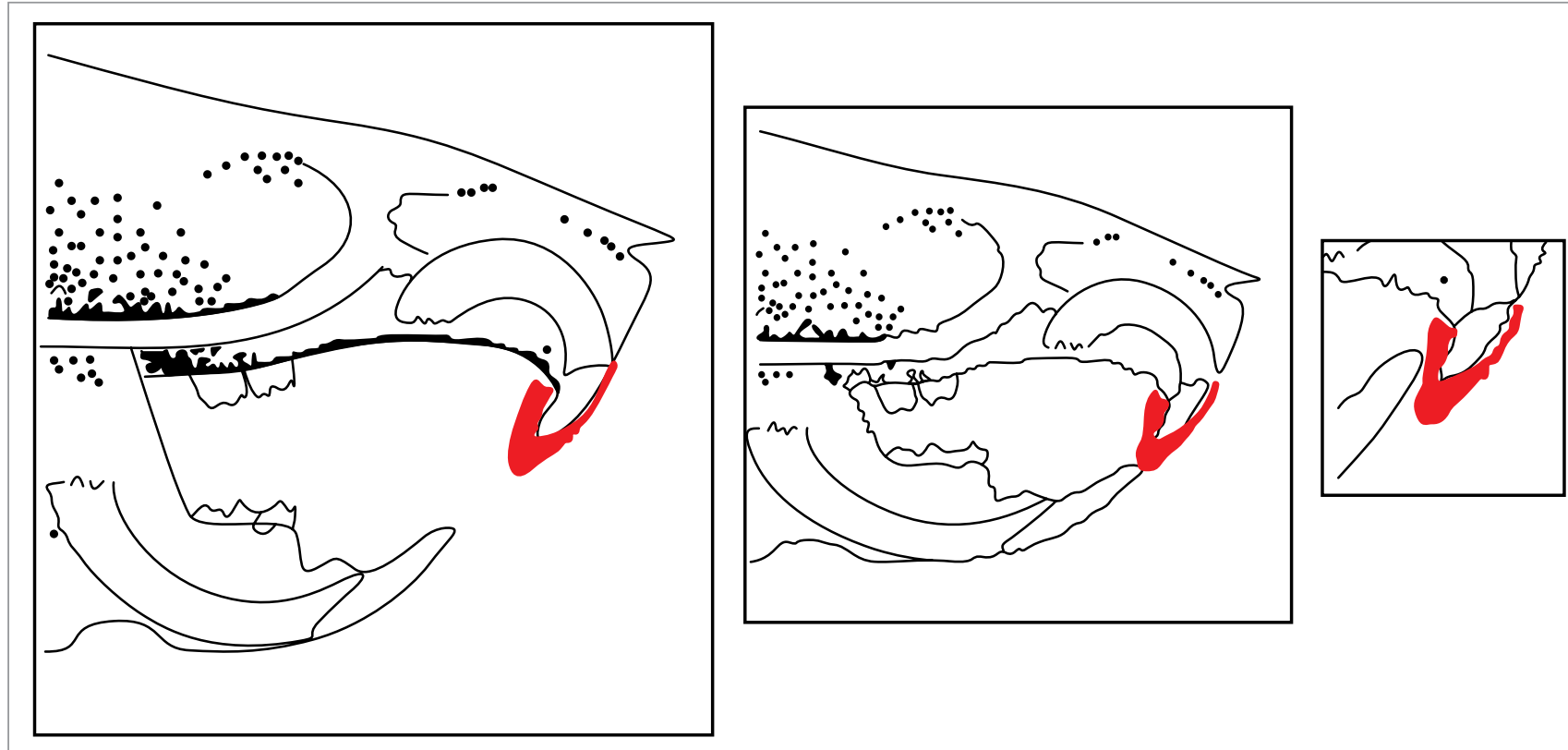

Figure 3 - Schematic sequence showing how the device was fitted onto the upper incisors of the rat, causing mandibular retrusion 
Immediately after death, the animals' heads were dissected and immersed in a fixing solution (Bouin) for 4 days. After consecutive changes of alcohols, the TMJ regions were dissected and decalcified in a solution containing $20 \%$ of sodium citrate, formaldehyde and distilled water for 5 days. The pieces were washed in running water for 4 hours in order to have the decalcifier removed. Histological routine was performed and the pieces subsequently embedded in paraffin, using the same plane of orientation with the ramus parallel to the surface of the block. Semi-serial sections were cut into sagittal sections of $7 \mu \mathrm{m}$ in the region of the condyle using a Leica RM $2145^{\circledR}$ microtome. Sections were stained with hematoxylin and eosin and mounted under a coverslip using Permount.

\section{Morphometric analysis}

The images were captured in high definition by an Optical Microscope (Motic BA400) and exported to a computer. Using ImageProPlus 4 (Media Cybernetics, USA) image analysis software, the various thicknesses of the proliferative, hyaline and hypertrophic layers were measured, totaling 6 sections from each animal.

In each section, 5 measurements were made for each layer, totaling 30 measurements of each animal (Fig 4).

\section{Statistical analysis}

Data were obtained through a double-blind study and subsequently processed with Statistica ${ }^{\circledR} 7$ software for statistical analysis. Data distribution did not show normal characteristics, which prompted the use of nonparametric tests. The groups were broadly assessed with the Kruskal-Wallis test.

\section{RESULTS}

Significant differences were found in total cartilage thickness, but only after 21 days (Table 1). In group E, after 7 days, a slight change was observed in the way the hyaline and hypertrophic layers were arranged (Figs $5 \mathrm{~A}$ and 5B). Total thickness showed no statistically significant difference compared to group $\mathrm{C}$ (Table 1), which could be confirmed by superimposing the data distribution curve (Fig 6A). Although the hypertrophic layer of group $\mathrm{E}$ seemed to be very similar to that of group $\mathrm{C}$ (Figs 5A and 5B), there was a slight decrease (9.60\%) in the hyaline layer and a subtle increase of $10.09 \%$ (Table 1) in the proliferative layer (Figs 6C and 6D).
After 21 days, histological changes were observed in group $\mathrm{E}$ (Figs 5C and 5D), across the entire condylar cartilage. There was an increase of $39.46 \%$ in the total layer (Table 1), reflected in an increase in the thickness of the hypertrophic (42.24\%), hyaline (46.92\%) and proliferative (17.70\%) layer, according to the data shown in Table 1 and Figures 6B, 6C and 6D.

Over 30 days of experiment, the condylar cartilage in group $\mathrm{E}$ seemed to be histologically similar to that of group $\mathrm{C}$ (Figs $5 \mathrm{E}$ and $5 \mathrm{~F}$ ). However, total thickness greater than $17.15 \%$ was observed due to an increased thickness in the hyaline and proliferative layers of $26.56 \%$ and $23.31 \%$ respectively, as shown in Table 1.

Both the experimental and the control group showed a significant decrease in the total layer of the condyle at the end of the experiment compared to C7 and E7 times, respectively.

Although the hypertrophic layer of group C showed an increase between C21 and C30 times (see table), such increase was not statistically significant and can be explained by the fact that during natural growth, a decrease in the total thickness of the condylar cartilage occurs (Figs 5A, 5C and 5E). In group $\mathrm{E}$, however, this pattern of development was altered, in particular with regard to thickness of the hyaline and hypertrophic (Figs 5B, 5D and 5F) layers.

\section{DISCUSSION}

During growth phase, the chances of achieving a successful treatment which is performed by means of functional orthodontic appliances that promote changes in mandibular posture, is higher, since cellular activity is more dynamic. The ages of the animals used in this study ranged from 5 to 9 weeks, spanning the prepubertal phase

Table 1 - Layer thickness: Total $(\mu \mathrm{m})$, hypertrophic $(\mu \mathrm{m})$, hyaline $(\mu \mathrm{m})$, proliferative $(\mu \mathrm{m})$ layers of the following groups: control group in 7 (C7), 21 (C21) and 30 (C30) days, and experimental group in 7 (E7), 21 (E21) and 30 (E30) days. $N=5$ animals per group.

\begin{tabular}{ccccc}
\hline & Total & Hypertrophic & Hyaline & Proliferative \\
\hline C7 & $240.51 \pm 39.43$ & $131.06 \pm 33.84^{\star}$ & $65.92 \pm 22.88^{\star}$ & $43.54 \pm 10.72$ \\
E7 & $245.90 \pm 39.46$ & $137.32 \pm 33.23$ & $60.15 \pm 18.22$ & $48.42 \pm 12.70$ \\
\hline C21 & $170.42 \pm 23.77^{\star *}$ & $72.92 \pm 17.28^{\star *}$ & $54.99 \pm 13.35^{\star \star}$ & $42.50 \pm 10.23^{\star *}$ \\
\hline E21 & $281.50 \pm 52.93$ & $126.26 \pm 31.33$ & $103.60 \pm 38.99$ & $51.64 \pm 28.93$ \\
\hline C30 & $157.29 \pm 24.89$ & $73.95 \pm 16.69$ & $51.94 \pm 13.86^{*}$ & $31.39 \pm 12.30^{*}$ \\
\hline E30 & $189.84 \pm 28.34$ & $78.18 \pm 15.06$ & $70.72 \pm 18.27$ & $40.93 \pm 13.42$ \\
\hline
\end{tabular}

${ }^{*} \mathrm{p}<0.05$ when compared to $\mathrm{E} 7$, ** $\mathrm{p}<0.05$ when compared to $\mathrm{E} 21, \# \mathrm{p}<0.05$ when compared to group E30. 


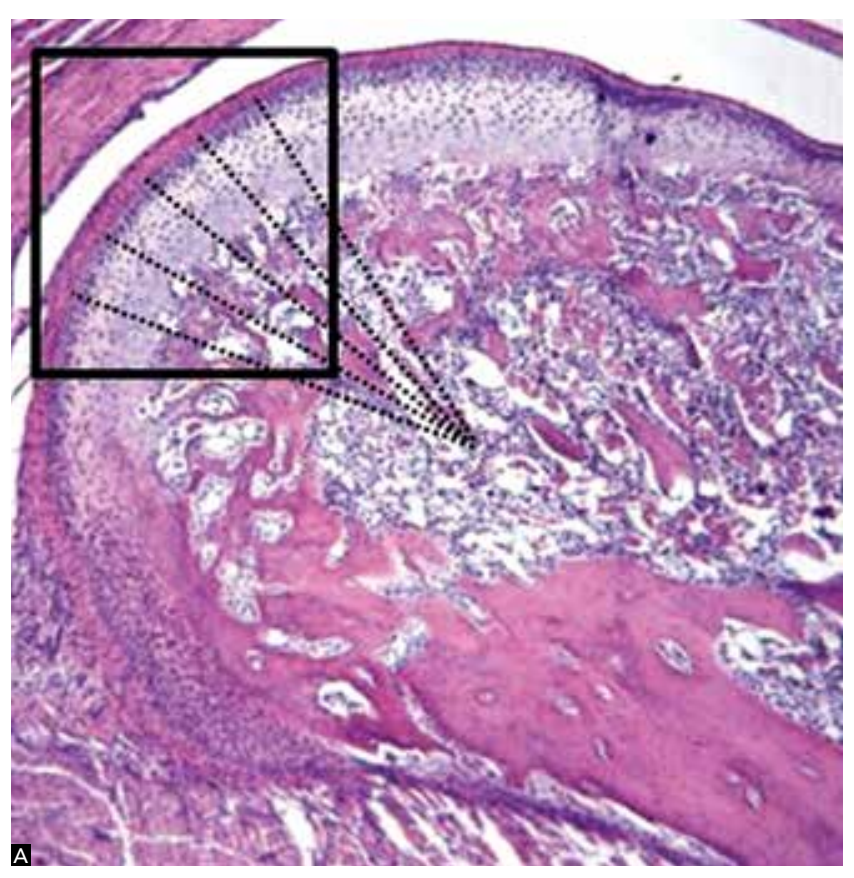

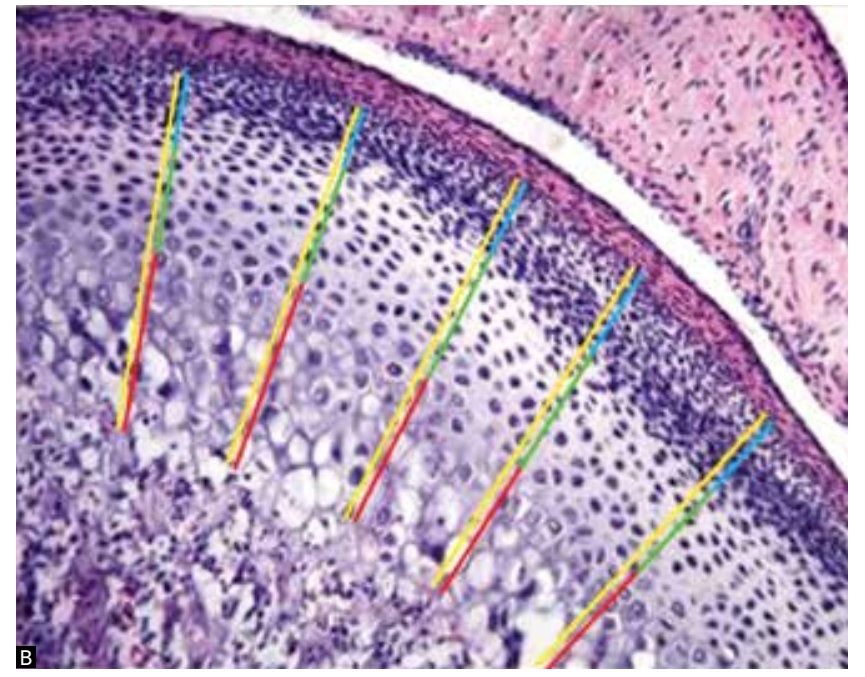

Figure 4 - A) 7- $\mu \mathrm{m}$ histological section of the mandibular condyle of a Wistar rat in the control group, after 7 days. Note the demarcated area where the images were captured for analysis (B). Measurements were made following the direction of the dashed line. B) Posterior region and part of the median region of the condyle, where total (yellow), proliferative (blue), hyaline (green) and hypertrophic (red) layers were measured.
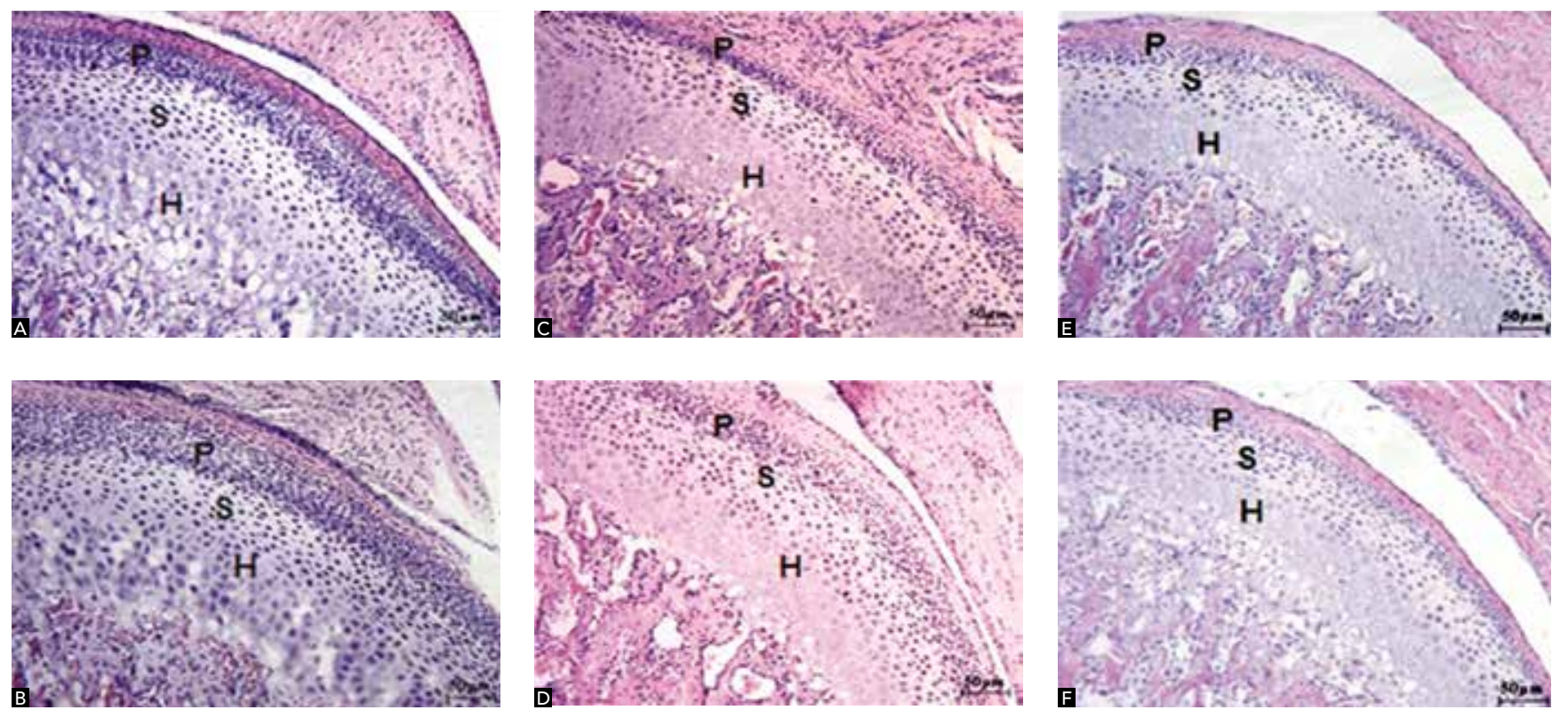

Figure 5 - Photomicrograph of the condylar region of rats showing the proliferative $(\mathrm{P})$, hyaline $(\mathrm{S})$ and hypertrophic $(\mathrm{H})$ regions which belong to the following groups: (A) control group after 7 days (B) Experimental group after 7 days. (C) control group after 21 days (D) experimental group after 21 days. (E) control group after 30 days (F) experimental group after 30 days. Staining: Hematoxylin and eosin. Calibration bar $(50 \mu \mathrm{m})$. 

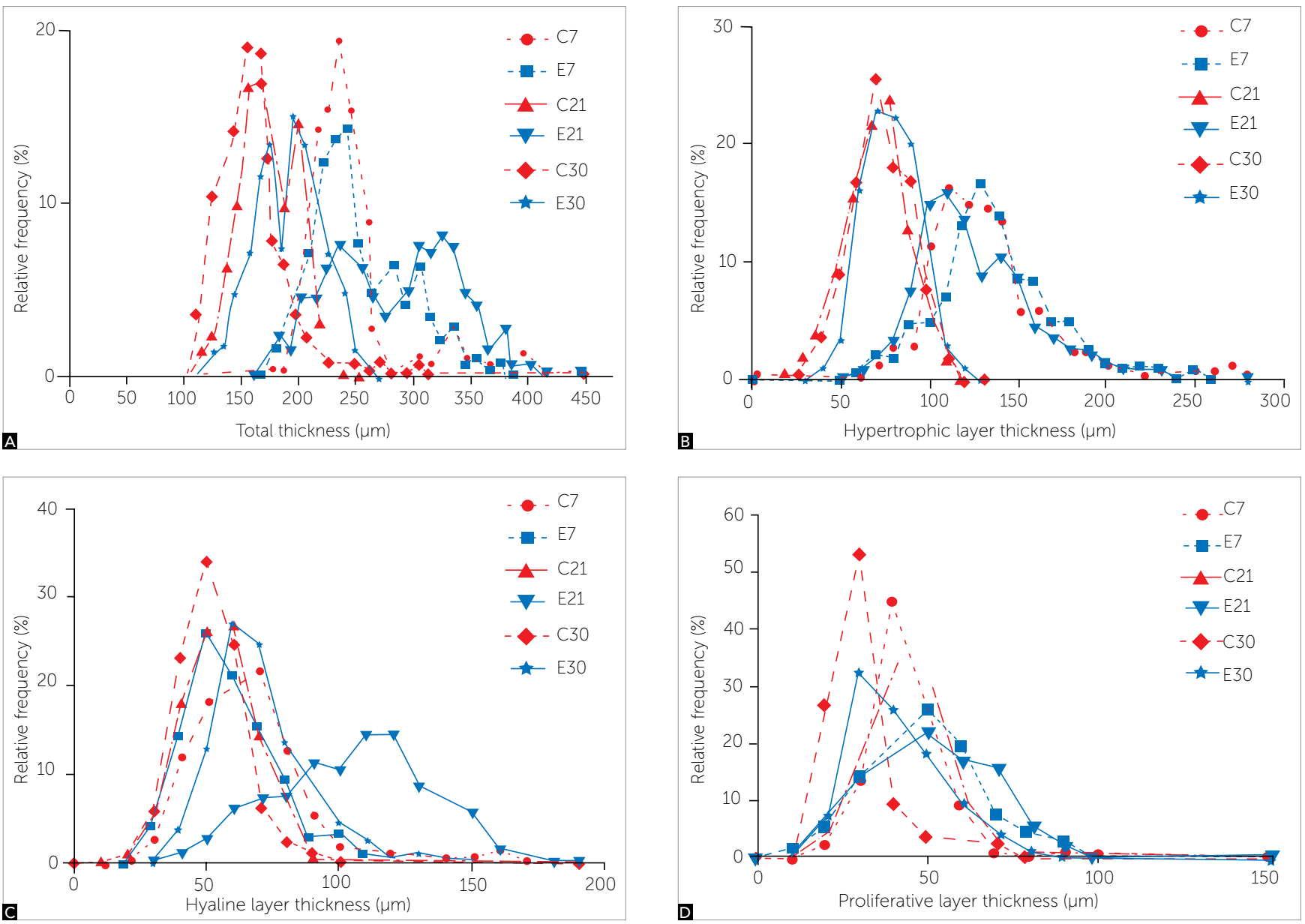

Figure 6 - Distribution of relative frequencies of the different layer thicknesses: (A) Total, (B) Hypertrophic, (C) Hyaline; (D) Proliferative, control groups after 7 (C7), 21 (C21) and 30 (C30) days and experimental after 7 (E7), 21 ( 21) and 30 (E30) days ( $n=5)$.

to the pubertal growth spurt stage. ${ }^{19}$ The experimental model that makes use of rat TMJs is widely accepted and studied due to its similarity to the human TMJ. ${ }^{17}$

Few reports in the literature involve changes in posture by mandibular setback. ${ }^{1,2}$ Some studies ${ }^{4,9,18}$ report cellular changes when the mandible is deviated to one side. The obtained results showed that after 14 days, there was an increase in growth in the condyle in the protruding or contralateral side, and a reduction in the non-protruding or ipsilateral side. Based on these data, the cartilage was expected to yield a total value below that of the control. However, the question is not so simple. The response mechanism of the condylar cartilage was markedly different on the $21^{\text {st }}$ day. There was an increase in total cartilage thickness in group $\mathrm{E}$, with the predominance of the hyaline and hypertrophic layers. It was not possible to determine that this increased cartilage thickness consisted of growth. A greater adaptive capacity of the condylar cartilage can be explored in appositional growth. ${ }^{19}$
It is known that the condylar cartilage has features that are similar to secondary cartilage, and that growth begins with the mesenchymal tissue (undifferentiated cells) covering the prenatal or postnatal condyle.

It should be recalled that during natural growth mesenchymal cells are further divided into smaller cells. Afterwards, these cells will reach their full size, resulting in migration of some of them out of the covering membrane and into the condyle. ${ }^{5}$ Differentiation occurs when the mesenchymal cells migrate to the cartilage, becoming immature cartilage cells. The new lineage of cartilage cells will then be added, not by means of mitosis of cartilage progenitor cells (interstitial growth), but by mitosis of undifferentiated mesenchymal cells. This growth mode, in which new external cells are added, consists of appositional increase. ${ }^{3,10}$ This study, therefore, did not disclose any increase in the proliferative layer, leading the authors to question any actual growth gains. 
According to Liu, Kaneko and Soma, ${ }^{9}$ in addition to the amount of growth, direction may also be altered. For example, on the side where the condyle is positioned a decrease occurs in the horizontal direction and an increase in the vertical direction. In this study, thickness of the posterior and middle portion of the cartilage was measured, which revealed an increase within 21 days.

Further studies are warranted to provide greater awareness and understanding of the characteristics of condylar cartilage when the mandible is retropositioned. New data could be observed if bone layer measurement were to be included and if the device were removed after 30 days, thereby promoting mandibular repositioning.

\section{CONCLUSIONS}

Application of a device to retrude the mandible modified the characteristics of the condylar cartilage in the experimental period. The most significant difference in cartilage thickness was observed after a period of 21 days, when stimulation promoted the prevalence of growth in the hyaline and hypertrophic layers. Mandibular retrusion produced a number of morphological and histological responses in the condyle and suggests the occurrence of a condylar and mandibular adaptation in rats. Clinically, this indicates that the use of orthopedic/orthodontic treatments can contribute to mandibular adjustments, facilitating mandibular positioning and basal bone interrelation.
1. Asano T. The effects of mandibular retractive force on the growing rat mandible. Am J Orthod Dentofacial Orthop. 1986:90:464-74.

2. Desai S, Johnson DL, Howes RI, Rohrer MD. Changes in the rabbit temporomandibular joint associated with posterior displacement of the mandible. Int J Prosthodont. 1996:9(1):46-57.

3. Dibbets JM. Mandibular rotation and enlargement. Am J Orthod Dentofacial Orthop. 1990:98(1):29-32

4. Fuentes MA, Opperman LA, Buschang P, Bellinger LL, Carlson DS, Hinton RJ. Lateral functional shift of the mandible: Part I. Effects on condylar cartilage thickness and proliferation. Am J Orthod Dentofacial Orthop. 2003:123(2):153-9

5. Garant PR. Oral cells and tissues. Chicago: Quintessence; 2003.

6. Gerber A, Steinhardt G. Disturbed biomechanics of the temporomandibular joint. In: Dental occlusion and the temporomandibular joint. Chicago: Quintessence; 1990. p. 27-47.

7. Goldstein BH. Temporomandibular disorders: a review of current understanding. Oral Surg Oral Med Oral Pathol Oral Radiol Endod. 1999:88:379-85

8. Hägg U, Rabie AB, Bendeus M, Wong RW, Wey MC, Du X, et al. Condylar growth and mandibular positioning with stepwise vs maximum advancement. Am J Orthod Dentofacial Orthop. 2008:134(4):525-36.

9. Liu C, Kaneko S, Soma K. Effects of a mandibular lateral shift on the condyle and mandibular bone in growing rats. Angle Orthod 2007:77(5):787-93

10. Luder HU. Perichondrial and endochondral components of mandibular condylar growth: morphometric and autoradiographic quantitation in rats. J Anat. 1994:185(3):587-98.

11. Owen AH. Orthodontic/orthopedic treatment of craniomandibular pain dysfunction. Part 2: posterior condylar displacement. J Craniomandib Pract. 1984:2(4):333-49.
12. Pullinger AG, Seligman DA, Solberg WK. Temporomandibular disorders. Part II: occlusal factors associated with temporomandibular joint tenderness and dysfunction. J Prosthet Dent. 1988;59(3):363-7.

13. Rabie AB, Hägg U. Factors regulating mandibular condylar growth. Am J Orthod Dentofacial Orthop. 2002;122(4):401-9

14. Rabie AB, She TT, Hägg U. Functional appliance therapy accelerates and enhances condylar growth. Am J Orthod Dentofacial Orthop. 2003:123(1):40-8.

15. Rabie $A B$, Xiong $H$, Hägg U. Forward mandibular positioning enhances condylar adaptation in adult rats. Eur J Orthod. 2004:26(4):353-8.

16. Ramirez-Yañez GO. Cartilagem condilar da mandibula: uma revisão. Ortop Rev Int Ortop Func. 2004;1(1):85-94

17. Ren Y, Maltha JC, Kuijpers-Jagtman AM. The rat as a model for orthodontic tooth movement: a critical review and a proposed solution. Eur J Orthod. 2004:26(5):483-90.

18. Sato C, Muramoto T, Soma K. Functional lateral deviation of the mandible and its positional recovery on the rat condylar cartilage during the growth period. Angle Orthod. 2006:76(4):591-7.

19. Shen G, Darendeliler MA. The adaptive remodeling of condylar cartilage: a transition from chondrogenesis to osteogenesis. J Dent Res. 2005:84(8):691-9.

20. Shen $G$, Hägg $U$, Rabie AB, Kaluarachchi K. Identification of temporal pattern of mandibular condylar growth: a molecular and biochemical experiment. Orthod Craniofac Res. 2005:8(2):114-22

21. Shen G, Zhao Z, Kaluarachchi K, Bakr Rabie A. Expression of type X collagen and capillary endothelium in condylar cartilage during osteogenic transition a comparison between adaptive remodelling and natural growth. Eur J Orthod. 2006:28(3):210-6.

22. Weinberg LA. The role of stress, occlusion, and condyle position in TMJ dysfunction-pain. J Prosthet Dent. 1983;49(4):532-45. 